\title{
THE STATUS AND CHALLENGES OF INDUSTRIAL ENGINEERING IN SOUTH AFRICA
}

\author{
C.S.L. Schutte ${ }^{1^{*}}$, D. Kennon ${ }^{1} \&$ W. Bam ${ }^{1}$
}

\section{ARTICLE INFO}

Article details

Submitted by authors 29 Nov 2015

Accepted for publication 16 Feb 2016

Available online $\quad 10$ May 2016

\section{Contact details}

Corresponding author

corne@sun.ac.za

\section{Author affiliations}

1 Department of Industrial Engineering

Stellenbosch University, South Africa

DOI

http://dx.doi.org/10.7166/27-1-1435

\section{ABSTRACT}

The industrial engineering discipline in South Africa is examined by introducing the context of the discipline and by revisiting its history. The drivers influencing the context and future of industrial engineering in South Africa are also considered, and the discipline is analysed in terms of the following aspects: university qualifications, employment in industry sectors, race and gender profiles, use and competence in industry, and income profiles. The analysis is based on a recent survey sent to practising industrial engineers, on membership data from the Southern African Institute for Industrial Engineering (SAIIE), and on two internal SAIIE investigations. The study concludes that the success of transformation, particularly in terms of race, has been limited. The results also indicate that there are an almost equal number of black and white industrial engineers, yet the majority of black industrial engineers have technical qualifications, while the majority of white industrial engineers have academic qualifications. The results indicate that this limits the use of black industrial engineers in industry and, consequently, the success of their careers. This in turn means that there are fewer black role models to attract young black students to the discipline. Some preliminary opportunities to unlock the increased transformation of the profession are identified.

\section{OPSOMMING}

Die bedryfsingenieurswese dissipline in Suid-Afrika is ondersoek deur eerstens die konteks van die dissipline te stel, die geskiedenis op te som, die drywers te identifiseer wat die konteks en toekoms van bedryfsingenieurswese beïnvloed, en dan die dissipline te analiseer in terme van die volgende aspekte: universiteit kwalifikasies, indiensneming in industrie sektore, ras en geslag profiele, benutting en vaardigheid in industrie, en inkomste profiele. Die analise is gebaseer op 'n onlangse meningsopname wat aan praktiserende bedryfsingenieurs gestuur is, op die Suider Afrikaanse Instituut van Bedryfsingenieurswese (SAIIE) se lidmaatskap data, en op twee interne SAlIE ondersoeke wat gedoen is. Die studie bevind dat die sukses van transformasie, veral in terme van ras, nog beperk is. Die resultate toon dat daar omtrent ewe veel wit en swart bedryfsingenieurs is, maar dat die meerderheid swart bedryfsingenieurs tegniese kwalifikasies het, terwyl die meerderheid wit bedryfsingenieurs akademiese kwalifikasies het. Die resultate toon dat dit die benutting van swart bedryfsingenieurs in industrie beperk en dus ook die sukses wat hul in hul loopbane behaal in terme van inkomste. Dit veroorsaak dat daar minder swart rolmodelle is om jong swart student na die dissipline te lok. Voorlopige geleenthede om transformasie in die professie te ontsluit word geïdentifiseer. 
Worldwide, industrial engineering has evolved into a major engineering and management discipline. The effective use of industrial engineering has contributed to an enhanced standard of living through increased productivity, improved quality of work, better quality and nature of services, and improvement in working environments [1].

The Institute for Industrial Engineering (IIE), which is similar to the Southern African Institute for Industrial Engineering (SAIIE) [2], defines industrial engineering as follows:

"Industrial engineering is concerned with the design, improvement and installation of integrated systems of people, materials, information, equipment and energy. It draws upon specialized knowledge and skill in the mathematical, physical, and social sciences, together with the principles and methods of engineering analysis and design, to specify, predict, and evaluate the results to be obtained from such systems." [3]

Industrial engineers (IEs) are thus responsible for the optimal design, implementation, integration, operation, improvement, and management of high-level systems. Such systems typically consist of chemical, electrical, electronic, mechanical, or civil components. These high-level systems generally exist within organisations as a mixture of equipment, information, people, capital, policies, processes, etc. IEs optimise these systems to improve quality and productivity and to reduce costs. Human and physical resources are thus combined and integrated to achieve specific objectives in these organisations [4].

Any engineering discipline follows technological trends, and the scope and focus therefore adjusts to these changing trends. Similarly, in industrial engineering, technology trends have had a major influence on how IEs are used in the industry. An example was the information system revolution of the 1990s, where industrial engineering was one of the first engineering disciplines to be faced with the enormity of the impact of information systems. This resulted in an identity crisis for industrial engineers, who were caught between the Industrial Revolution and the new challenges of the information system era [5].

In addition, within the South African context, where major socioeconomic changes have occurred since 1994, IEs have been exposed to a number of unique challenges that are non-existent or less dominant in other fields. By examining the status of industrial engineering in South Africa, this paper not only identifies the most pertinent of the unique challenges the discipline faces, but also identifies approaches to address some of these challenges.

\section{THE HISTORY OF INDUSTRIAL ENGINEERING IN SOUTH AFRICA}

The need for industrial engineers in South Africa arose with industrialisation in South Africa, when major industries such as ESCOM (now ESKOM) and ISCOR (now ArcelorMittal South Africa) were established in the 1920s. World War II, which was a time of restricted imports, helped to advance industrialisation. This led to more sophisticated requirements in order to manage mass production and more sophisticated manufacturing technologies. In addition, in 1940 the Industrial Development Corporation of SA Limited (IDC) was established by Act of Parliament, with the main objective of promoting the establishment of industrial undertakings and the development of existing enterprise on sound business principles. The IDC assisted and pioneered many industries and projects, the most notable being SASOL's oil-from-coal project [6].

The increasing number of skilled people drawn to the steadily-developing manufacturing industry eventually created the need for a collective formal body representing what were then referred to as 'production engineers'. The nomenclature later included the term 'manufacturing engineers'. The South African Association of Production Engineers was formed in 1943, and only later evolved into the South African Institute of Industrial Engineers (SAIIE), which was launched at the end of 1981. SAIIE was given formal recognition in 1984 when it was acknowledged as an institute in terms of engineering legislation that recognised the industrial engineering profession in South African law as a separate branch of engineering [6]. A timeline of the academic development of industrial engineering in South Africa is depicted in Figure 1. 


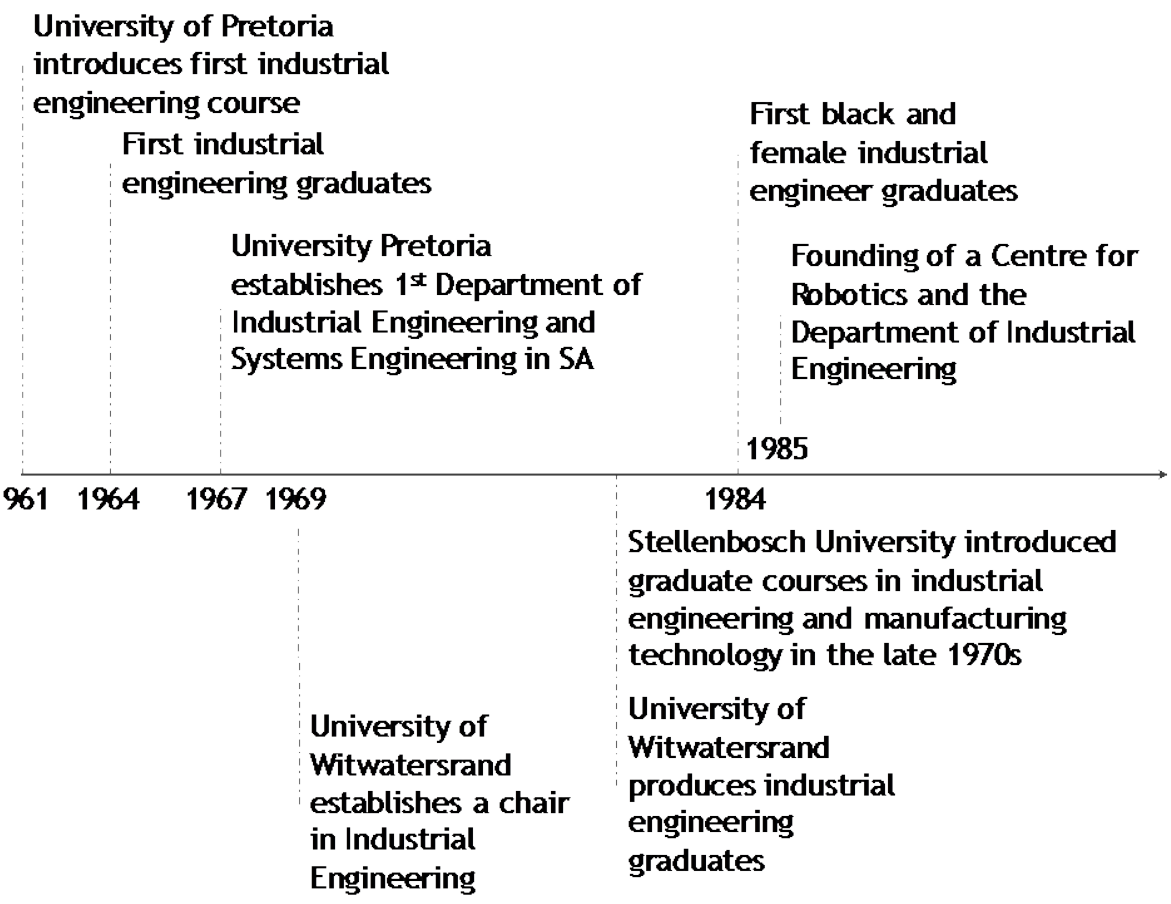

Figure 1: The development of industrial engineering as an academic discipline in South Africa (adapted from Sperotto [6])

Today, the study of industrial engineering culminates in an academic qualification (BEng) at four academic universities, and in technical qualifications (BTech and NDip) at nearly all the technical and comprehensive universities in South Africa.

\section{SOUTH AFRICAN INDUSTRIAL ENGINEERING DRIVERS}

To understand the direction of the industrial engineering profession in South Africa, it is useful to consider the specific trends and drivers that describe and determine this direction. Trends in industrial engineering research provide insight into the focus of industrial engineering technology uptake and development. Trends in the structure of the South African economy provide an important context within which to view industrial engineering in the country. The nature of the educational pipeline for IEs is an important determinant of the future of the profession.

\subsection{Technology trends}

One way of determining the current level of technology uptake in a discipline is to compare the research within the country with worldwide trends. This can be achieved by analysing and comparing the scope and trends of the research published in international and regional journals.

Dastkhan and Owlia [7] analysed the trends in international industrial engineering research over the three decades from 1980 to 2007. The publications on different industrial engineering topics from four main international publishers - Pergamon, Elsevier, Springer, and Emerald - were studied. Data derived from 7,114 papers were analysed and categories were defined through a survey of keywords in the publications, themes of industrial engineering conferences, and ideas of experts in this field. The analysis showed that the proportion of publication outputs on production management had decreased from 2000 to 2007, while research on topics such as intelligent systems, supply chain management, and information technology had increased. As a result, the researchers expressed an expectation that, in an international publication context, most future industrial engineering research would be focused on subjects such as information technology, intelligent systems, optimisation, quality, and supply chain management. These findings are shown in Figure 2. 


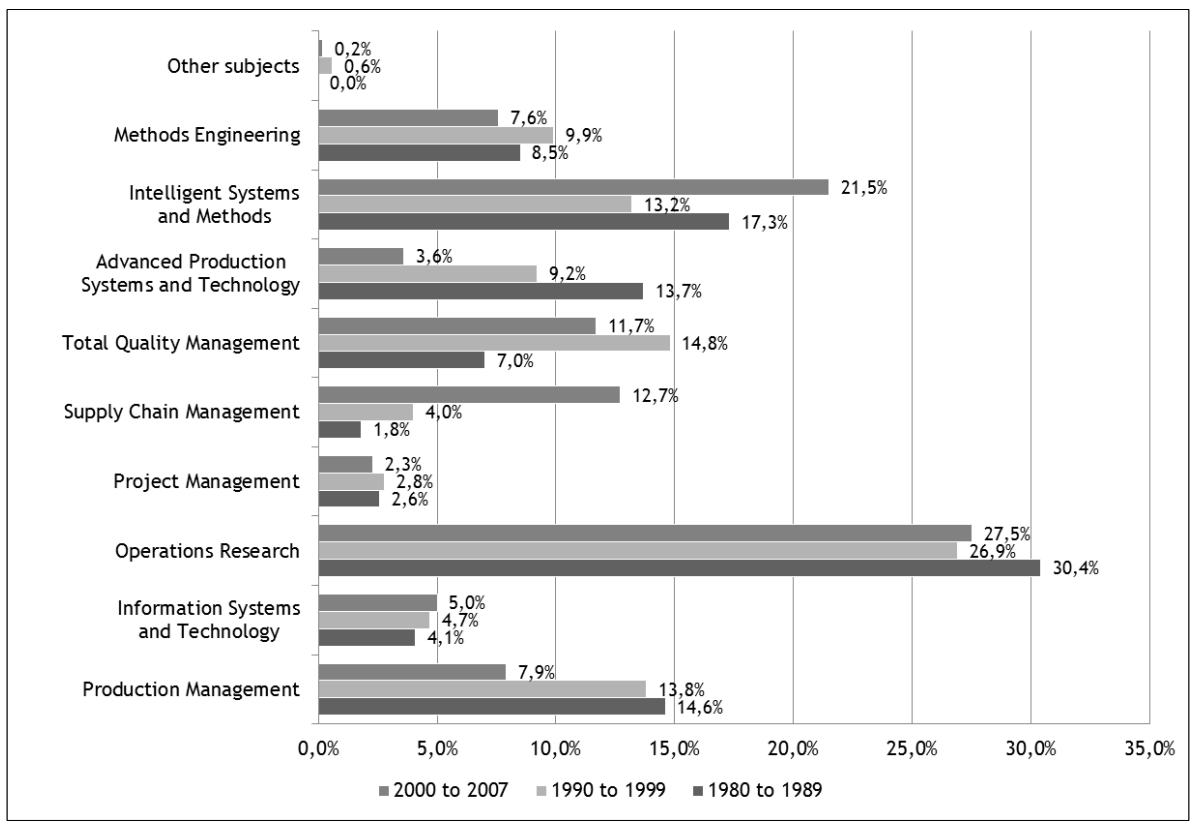

Figure 2: Proportion of research on different industrial engineering topics in international publications (adapted from Dastkhan and Owlia [7])

For similar reasons, an analysis was performed on the South African Journal of Industrial Engineering (SAJIE) in 2010. At that time, a textual library of 283 journal articles capturing a 22year history was available for a semi-automated textual analysis using Latent Dirichlet Allocation (LDA), a statistical topic model technique [8]. The result of this study is shown in Figure 3.

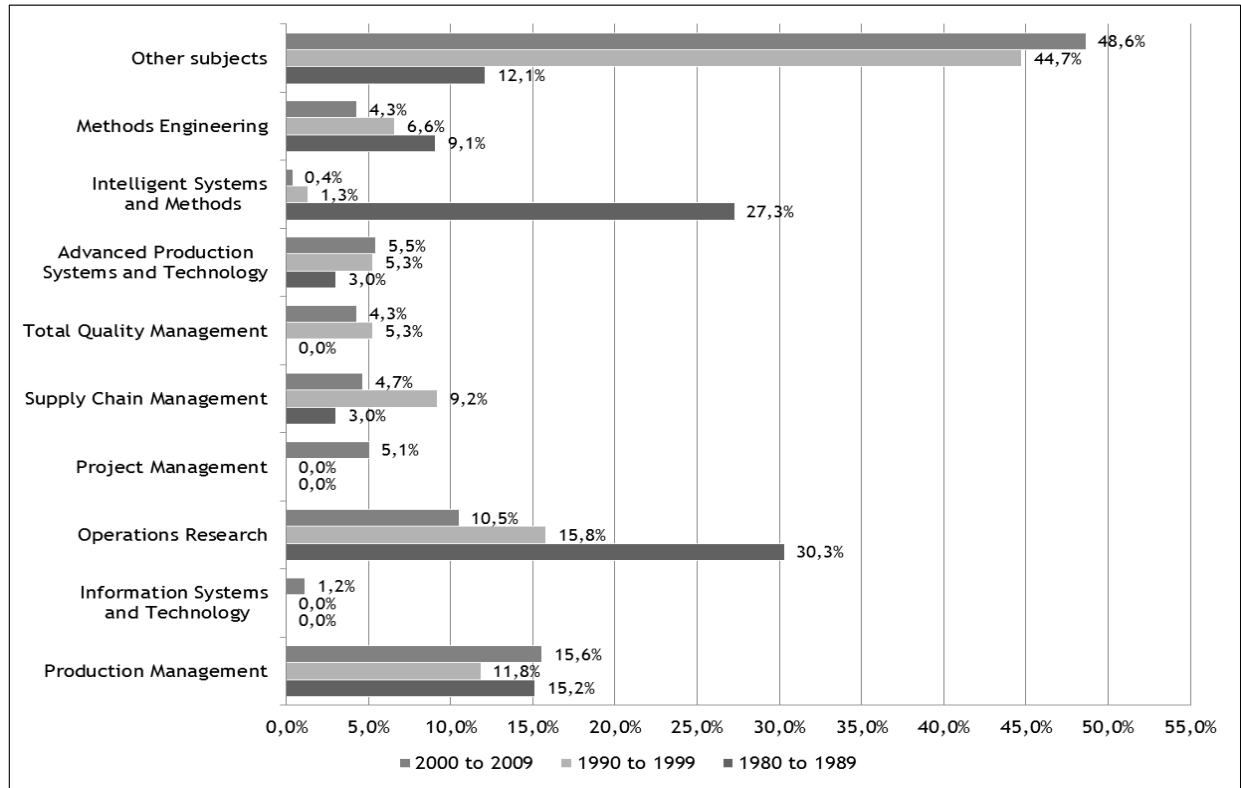

Figure 3: Proportion of research on different industrial engineering topics in SAJIE's articles (adapted from Uys et al. [8])

A successful comparison of the results of the two studies therefore lies in the ability to relate and interpret Figure 2 and Figure 3. For instance, Figure 2 indicates that $26.9 \%$ of all articles written across the international spectrum between 1990 and 1999 were in the category of Operations Research. From a South African perspective, Figure 3 indicates that during the same period, 15.8\% of SAJIE's articles corresponded with the Operations Research category. 
The most significant difference is the high percentage of 'other subjects' found in the 1990-1999 and 2000-2009 periods in Figure 3. Each of the 50 SAJIE topics not allocated to one of the nine specific categories determined by Dastkhan and Owlia [7] was grouped under 'other subjects'. Most of these topics are more management-oriented, which may be attributed to the fact that SAJIE also publishes articles in the fields of engineering and technology management (ETM).

Relating the results from the two studies can be simplified by reducing the ETM influences in the SAJIE research outputs by removing the 'other subjects' category from the comparison. The 'other subjects' category in itself only constitutes $0.2 \%$ of international IE trends from 2000 to 2007; so the omission of this category for the purpose of comparison is justified. Figure 4 shows the recalculated SAJIE percentages across the nine specific categories, pairing the 2000-2009 series from Figure 2 and Figure 3, thereby objectively comparing the recent articles of this study with the study done by Dastkhan and Owlia [7]. This was also combined with another analysis done the following year [9], similarly using LDA on the well-known journal Computers and Industrial Engineering (CalE). These results are shown in Figure 4.

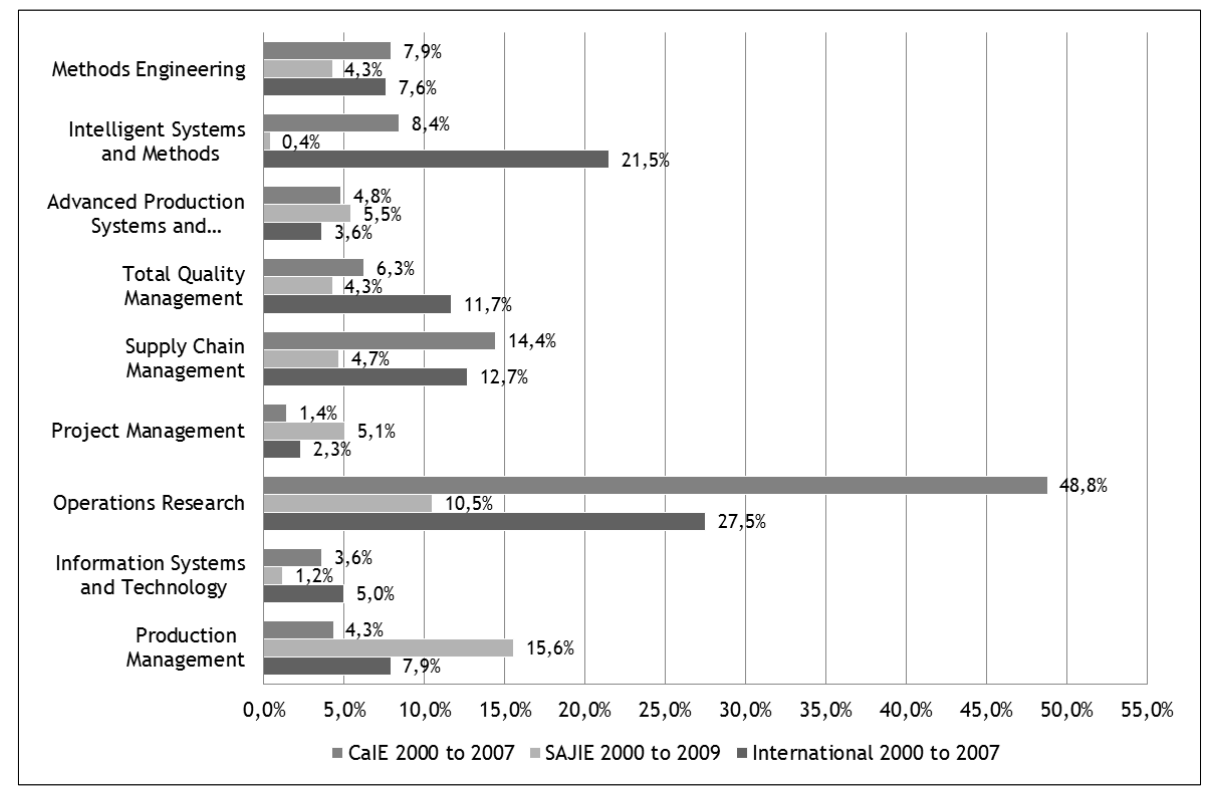

Figure 4: Proportion of research on different industrial engineering topics in SAJIE, CalE, and internationally (adapted from Uys et al. [9])

By comparing the respective percentages of CalE with those of international studies, it can be seen that CalE closely corresponds with international studies in terms of the categories used by Dastkhan and Owlia [7], with the exception that CalE seems to have a much stronger coverage in the Operations Research category and less coverage in the Total Quality Management and Intelligent Systems and Methods categories. This is probably not a surprising observation, as each journal builds a reputation for a focus area over its lifetime, which is determined by the preferences of the editorial board and authors who have published in the journal. This shows in CalE articles and in their stronger Operations Research focus compared with other industrial engineering journals. The reduced emphasis on Operations Research in SAJIE may also be due to the existence of a local journal, Orion, which focuses specifically on Operations Research.

However, from Figure 4 it is evident that, aside from ETM research, the main South African industrial engineering research area in recent publication history was Production Management, followed by Operations Research and Advanced Production Systems and Technology. Internationally, however, Operations Research was the primary industrial engineering research publication area, followed by Intelligent Systems and Methods and Supply Chain Management. The SAJIE topic spread leans towards Project Management and production-oriented research in comparison with the relevant international trend. The proportion of South African industrial engineering publication outputs seem to be on a par with recent international trends in the 
subject areas of Information Systems and Technology, Operations Research, Supply Chain Management, and Total Quality Management.

It would thus seem that the South African industrial engineering research focus leans more towards the traditional production engineering research topics and less towards the computer sciencerelated topics of Intelligent Systems and Methods, Information Systems and Technology, and Operations Research. This could be due to the particular history of industrial engineering in South Africa and its development from production engineering. A further explanation is that articles that fall in the dominant production engineering categories are more important to the local environment, due to the structure of the local economy. That is to say, the manufacturing industry in South Africa generally implements known technologies within the local environment (project management) and generally does not export manufacturing technologies (Intelligent Systems and Methods, and Information Systems and Technology). However, that does not explain the strong presence of Advanced Production Systems and Technology research. It may also be that articles in the underrepresented categories are published instead in international journals due to their international relevance. It may thus be useful also to compare the results with local journals in countries with economies similar to that of South Africa. This will enable a comparison with another journal with a local focus and with similar local technology requirements. Furthermore, a more in-depth analysis of the growing 'other' category may be useful, particularly since this category has grown significantly in importance. Given the changes in the local economy outlined in the next section, this change towards management and other non-traditional industrial engineering research areas might indicate an adaptation of the profession to the changing environment.

\subsection{South African economy}

The South African economy has experienced significant growth over the past 20 years, with GDP prices as at 2010 having increased by $89 \%$ over the period 1993 to 2014 .

However, as shown in Figure 5, the contribution to GDP per industry sector has changed since 1993. Mining and manufacturing were significant activities in 1993, but these have since decreased considerably from $16.7 \%$ to $8.6 \%$ and from $15.9 \%$ to $13.5 \%$, respectively. The finance, real estate, and business services industry has become the most dominant sector, surpassing government services, mining, and manufacturing.

This means that IEs are now employed in a very different economy than they were 20 years ago, and as a consequence, one can expect that how IEs are used has also changed.

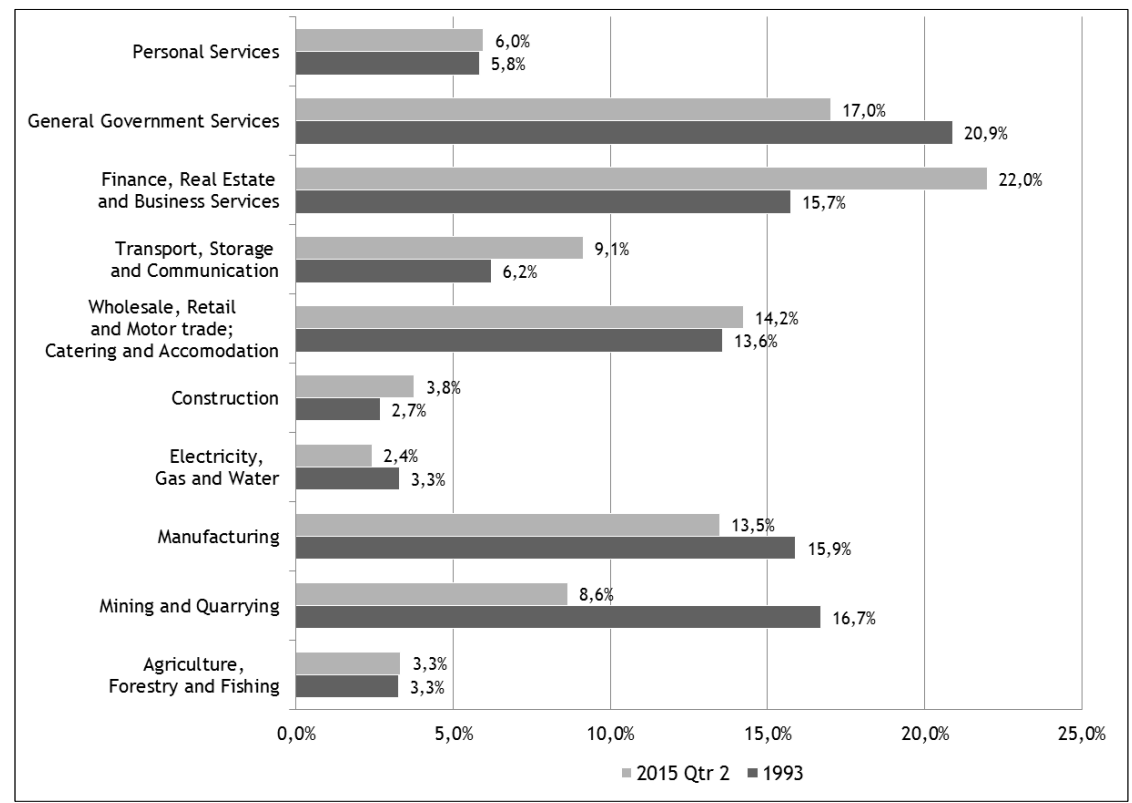

Figure 5: Percentage of GDP per industry [10] 


\subsection{South African education pipeline for IEs}

In the 2012 Infrastructure Sector Research Survey by executive search firm Landelahni Business Leaders Amrop SA, the engineering graduate skill shortage was highlighted [11]:

"Of the 600000 candidates who wrote school-leaving examinations in 2009, only 22\% passed maths higher grade and only $7 \%$ passed physical science higher grade. In the same year, only $28 \%$ of students in public higher education institutions were enrolled for programmes in science, engineering and technology."

In addition, total graduations (degrees and diplomas) across all engineering disciplines between 1998 and 2010 numbered 70,475, at a 13.8\% pass rate. Of this total, 29,280 engineers graduated with degrees from universities, which is an average of 2,252 per year. While there was an upward trend for black and female engineering graduates, the average university pass rate of all engineering students was $16.0 \%$, far below the international average of $25.0 \%$ [11].

An industrial engineering occupational team compiled a report as part of a working group initiated by the Department of Higher Education and Training (DHET) in 2013, in order to determine the scarce skills for 18 strategic integrated projects (SIPs) in South Africa. One of the key findings of this report was that the supply of IE practitioners had not matched the significant demand-side growth in roles requiring IE skill sets, whether or not they were defined as such [12]. This has been underlined by the DHET, which placed industrial and production engineers at No. 8 on its scarceskill list [13]. This points towards a significant opportunity that should be grasped by the tertiary educational system in South Africa. Unfortunately, this is only possible with the support of secondary education and the proactive development of learning capabilities throughout the schooling system.

Thus, from the technology, economic, and educational drivers presented, it appears that there is a shortage of IEs in the country. Furthermore, it seems that with the shift in the economy towards finance, real estate, and business services, the requirements for the industrial engineering profession are also shifting. Thus the technology development within IE in South Africa seems to be shifting towards the engineering and technology management domain, categorised as 'other' in the presented analysis.

\section{SOUTH AFRICAN INDUSTRIAL ENGINEERING STATUS}

To ensure that the identified shortage of IEs is addressed, it is necessary to understand better the supply of and demand for IEs in the South African context. This section will thus explore the following industrial engineering aspects:

- $\quad$ university studies and qualifications;

- $\quad$ employment in the industry sectors;

- $\quad$ race and gender profiles;

- $\quad$ use and competence; and

- income profiles.

The following vehicles were used to gather data to reflect the status of industrial engineering in South Africa:

- $\quad$ An IE survey on SurveyMonkey [14] was distributed to SAIIE members, industrial engineering Facebook and Linkedln groups, and industrial engineering alumni of the University of Pretoria, Stellenbosch University, Cape Peninsula University of Technology (CPUT), and Tshwane University of Technology (TUT). The number of responses received was 415.

- The presidential address at the SAIIE AGM of 2011 [15] and additional data analysis on the SAlIE member database containing 2,088 members in August 2015, with the approval of the current SAIIE president.

- An internal SAlIE investigation into the requirements for BTech and NDip graduates in industrial engineering, performed by LHA Management Consultants in 2015 [16].

- Ad hoc enquiries related to the racial composition of programmes at academic industrial engineering departments in South Africa. 


\subsection{University studies and qualifications}

The institution where each IE received his or her highest qualification was analysed. Each university was categorised as one of the following:

- Academic university, sometimes termed 'traditional university' (e.g. University of Pretoria, Stellenbosch University, North-West University Potchefstroom Campus);

- Comprehensive university (e.g. University of Johannesburg, Nelson Mandela Metropolitan University);

- Technical university (e.g. TUT, CPUT); or

- $\quad$ Foreign university (i.e. situated outside the borders of South Africa).

Since the comprehensive universities all deliver technical qualifications in industrial engineering, it makes sense to group comprehensive and technical universities together for the purposes of this analysis. Owing to the large number of foreign universities appearing in the datasets and the variety of classification systems used internationally, no attempt was made to categorise foreign universities as either academic or technical.

It is important to note that the survey data is skewed towards those universities where the authors had alumni access. The SAIIE member database is therefore more representative of the university profile. It was found that the majority of IEs were sourced from an academic university (see Figure 6), which was also true of the 20- to 29-year age group (not shown). The picture did not change when the focus was placed on older groups; a significant portion (24\%) of IEs in the 40 - to 49-year age group originated from foreign universities. There is currently a trend where well-qualified and experienced mid-career IEs from neighbouring countries such as Zimbabwe emigrate to South Africa to further their careers.

When one examines the profile of highest qualifications in Figure 7, the results of 'university type' analysis in Figure 6 and Figure 7 confirm that the majority of IEs have academic qualifications. The graph in Figure 7 also shows that $33.0 \%$ of IEs in the SAlIE member database have a postgraduate qualification (indicated in dark grey), and 3.8\% have degrees at a doctoral level. The 'None' category depicts the student members of SAlIE.

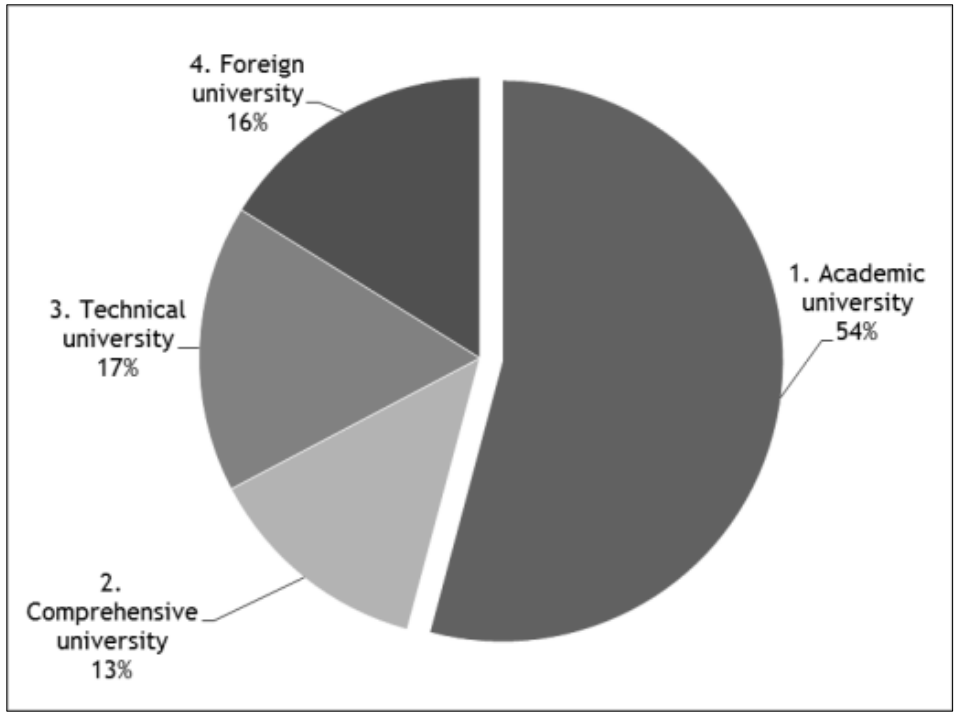

Figure 6: Qualifications at university types for all ages (Source: SAllE member data) 


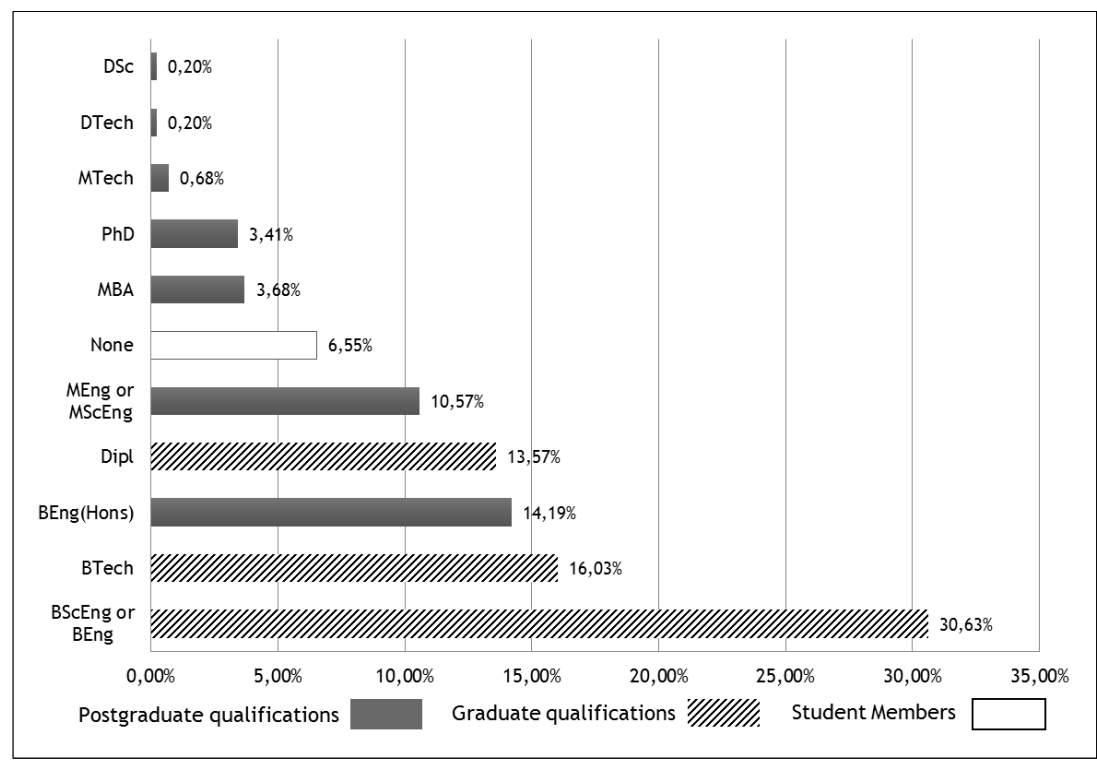

Figure 7: Highest qualifications as a percentage of the SAIIE member population (Source: SAIIE member data)

\subsection{Employment in the industry sectors}

The employment aspects of all IES in the SAIIE member database and the IE survey were analysed and categorised into industry sectors. A surprising aspect of the industry sector analysis was that the manufacturing sector is still the largest employer of IEs (see Figure 8). This was confirmed by analysing the 13 largest employers in the SAIIE member data (see Figure 9). When one considers the number of IEs employed by the 13 largest employers, it is interesting to note that IEs are distributed over a large number of employers, and that employer No. 13 employs only about 10 IEs in the database sample. IEs therefore work in very small numbers in most organisations. This contributes to identity and possible career advancement issues, especially for young inexperienced IEs.

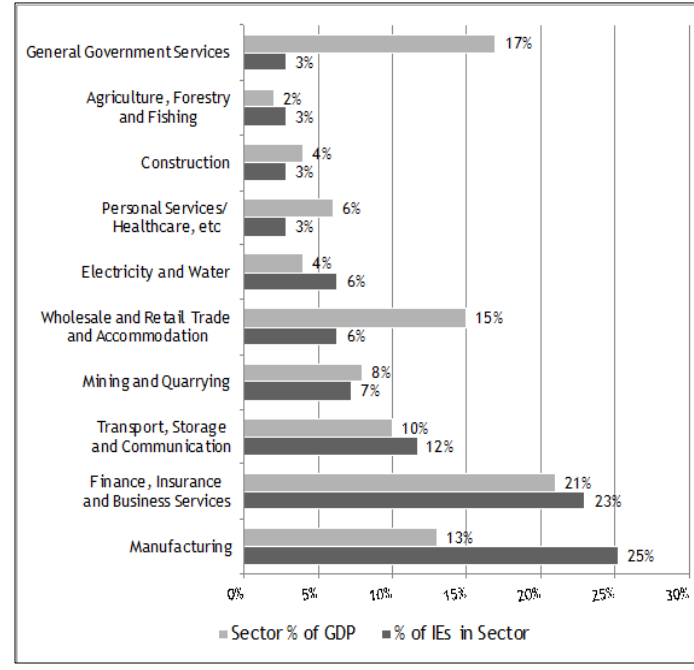

Figure 8: Percentage of IEs employed per industry sector vs size of the sector (Source: IE survey and Statistical Release [10])

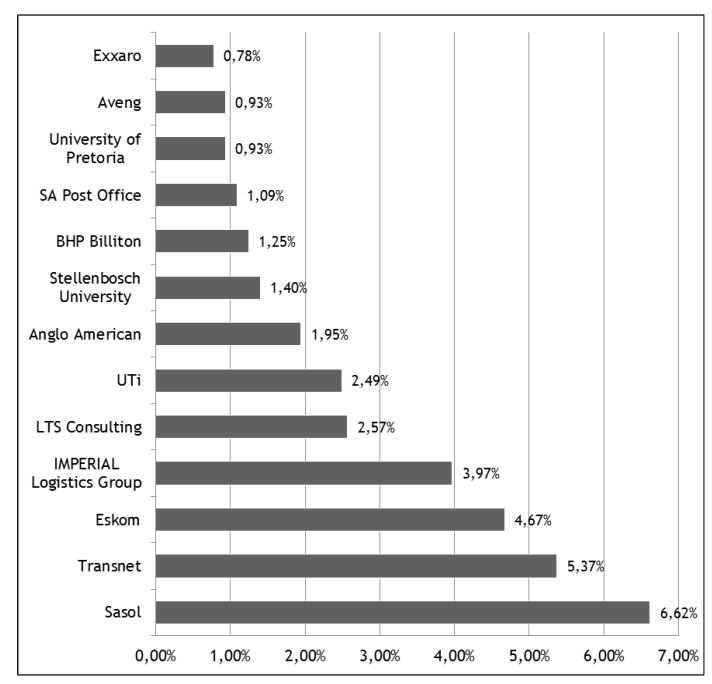

Figure 9: Thirteen largest IE employers as a percentage of members (Source: SAllE member data and Schutte [15])

A useful analysis was to compare the percentage of IEs in each industry sector with the size of the industry sector shown in Figure 8. Another recent survey performed by LHA Management Consultants for SAIIE confirmed that IEs were still mainly employed in 'traditional' sectors such as 
manufacturing $(13.5 \%$ of GDP) and construction (< $40 \%$ of GDP), and fewer were employed in the wholesale and retail trade (14.2\% of GDP) [16]. General government services comprised $17.0 \%$ of the GDP, but less than $3.0 \%$ of IEs work in this sector. This thus represents a significant opportunity for IEs, who can make a meaningful contribution in bringing efficiency to a sector that is often considered inefficient. This discrepancy might also point to a government reliance on consulting IEs when industrial engineering expertise is required.

When the employment per industry sector is further analysed per degree type, another picture emerges. As Figure 10 shows, IEs with an academic qualification (sample of 237) can generally be seen practising their trade in most of the industry sectors, whereas comprehensive (sample of 21) and technical graduates (sample of 39) find themselves predominantly in the manufacturing, finance, insurance and business services, and education and/or research, with a small number in transport. This seems to indicate the transferability and wider application of an academic qualification versus the specialisation of technical qualifications.

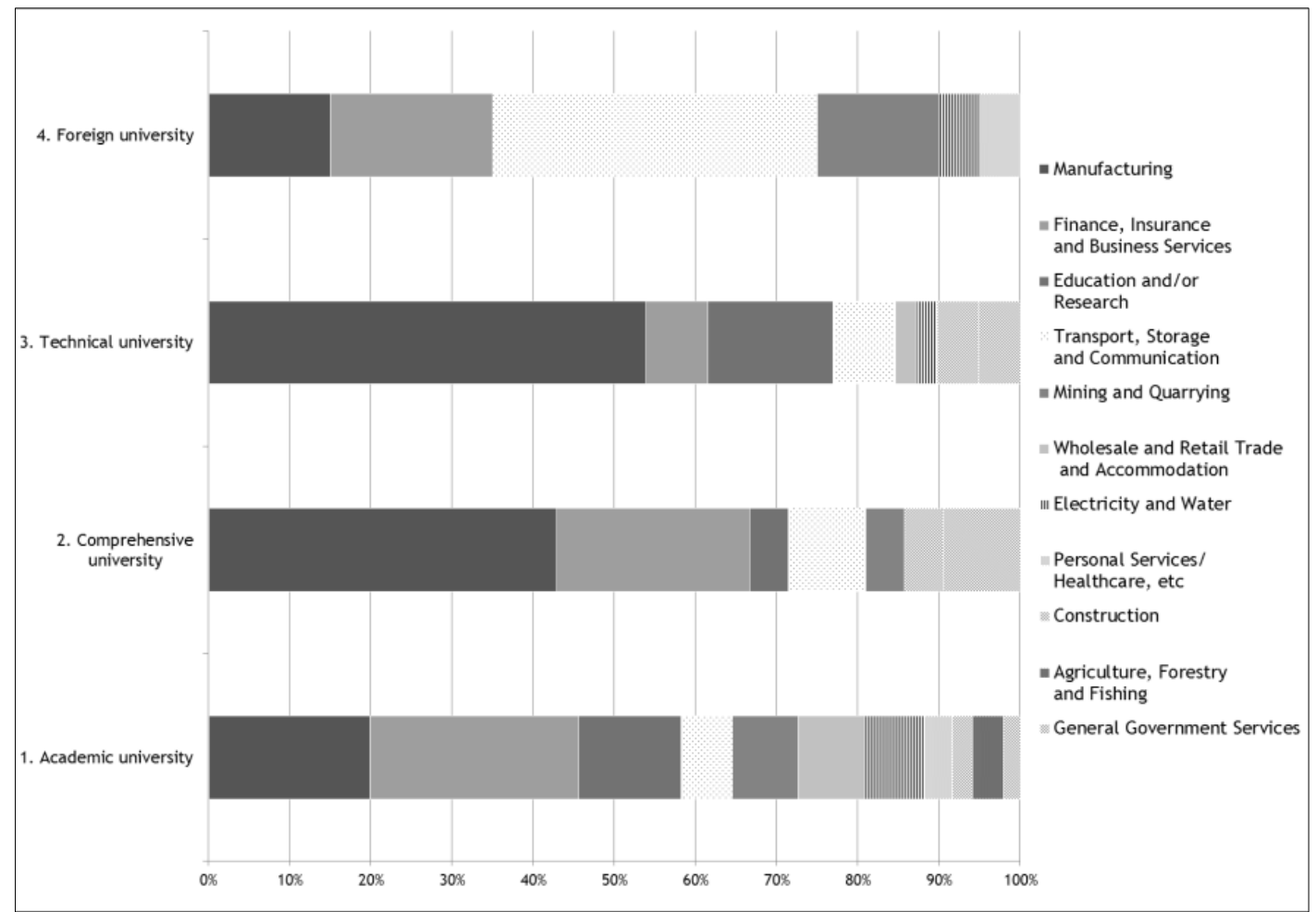

Figure 10: A qualification's affinity to a certain industry sector (Source: IE Survey)

\subsection{Race and gender profiles}

As a discipline, industrial engineering is not isolated from the unequal representation challenges faced by engineering in South Africa and globally.

Figure 11 shows that for all SAIIE registered members, the white male group is still the largest (44.3\%), despite only representing 4.1\% [17] of South Africa's population. Figure 12 shows the same data, but filtered for all IEs younger than 40 . This indicates that the ratio of both black and female IEs is increasing.

It is also promising that the number of black IEs is now almost equal to the number of white IEs, which indicates some success with transformation. However, considerable transformation in terms of both race and gender is still required for the IE profession to reflect a representative demographic composition. 


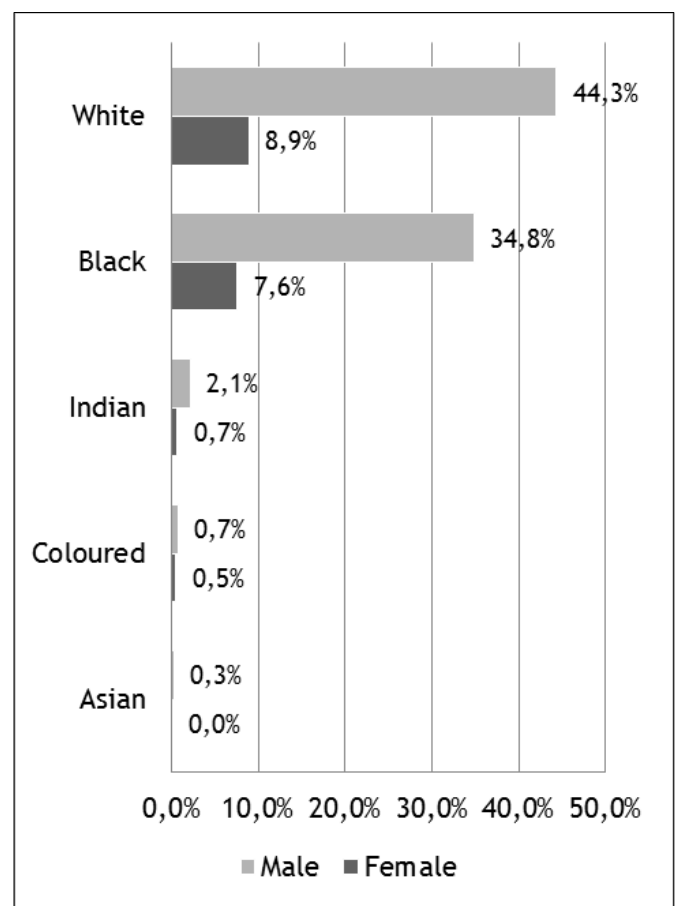

Figure 11: Race and gender across all ages (Source: SAlIE member data)

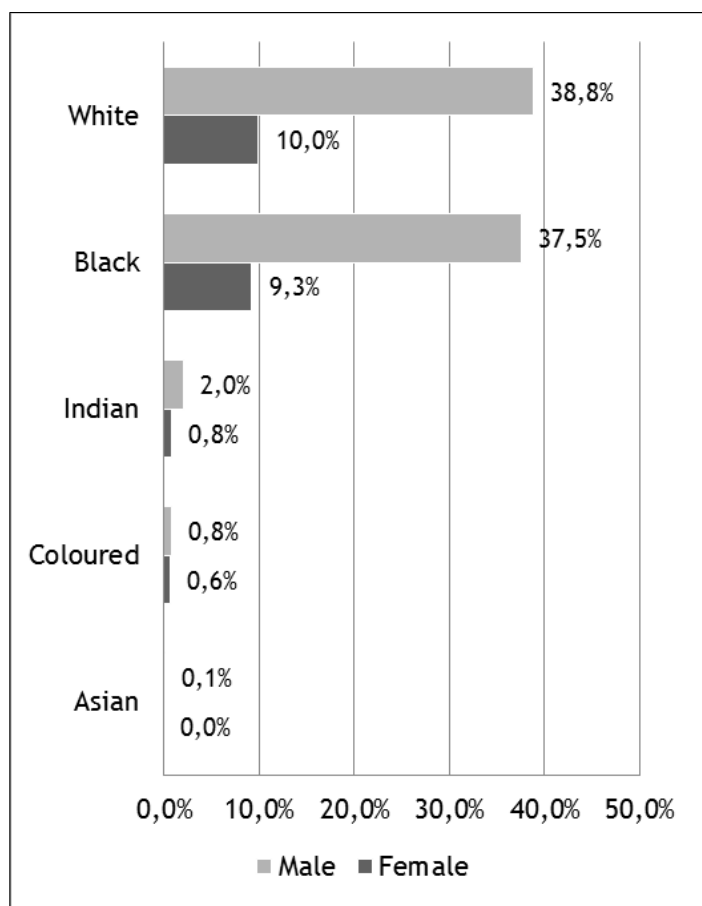

Figure 12: Race and gender of IEs younger than 40 (Source: SAllE member data)

However, when the university type profile per race is examined, a worrying picture emerges, which is confirmed by both datasets (SAIIE data and the IE survey data). Approximately $90 \%$ of white IEs in the data have an academic qualification compared with less than $20 \%$ of black IEs. The sample sizes for the other race groups are very small, so the similarities between the datasets are less apparent. Similarly, a disproportionately small percentage of white students enrol for the technical qualifications ( $2 \%$ in technical universities and $5 \%$ in comprehensive universities). The consequence is the following, as shown in Figure 13:

- $\quad$ Academic programmes are $83 \%$ white and $17 \%$ black, coloured, and Indian (BCl).

- $\quad$ Comprehensive university programmes are $75 \% \mathrm{BCl}$ and $25 \%$ white.

- $\quad$ Technical university programmes are $95 \% \mathrm{BCl}$ and only $5 \%$ white.

- $\quad$ Foreign university graduates are $90 \% \mathrm{BCl}$ and $10 \%$ white.

The figures provide a clear picture of the disparity regarding race and education type, and filtering on a younger age bracket provides an even more discouraging picture.

In order to confirm and understand the racial profiles of the IE academic university students, additional information regarding the 2015 first and final year IE class compositions was requested from the academic programmes at Stellenbosch University (SU), University of Pretoria (UP) [18], University of Witwatersrand (Wits) [19], and North West University (NWU) [20]. Since the data are of a sensitive nature, only a summarised version is given in Table 1 . The table shows that the four industrial engineering academic programmes currently have only between 23 and $25 \% \mathrm{BCl}$ students. This is an improvement over the $17 \% \mathrm{BCl}$ component with academic qualifications found in SAllE member data.

UP has the greatest number of industrial engineering academic students, with SU coming second when final-year students are considered (see Figure 14 and Figure 15 for the distribution of all students in the academic programmes, irrespective of race). 


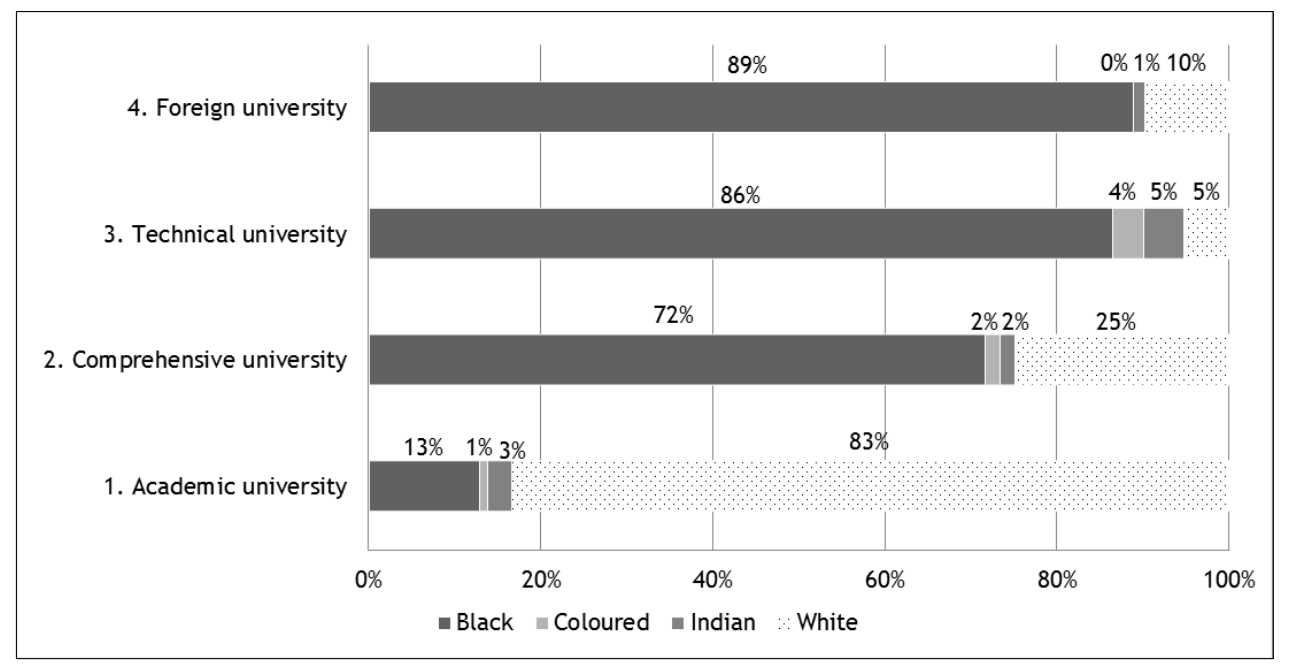

Figure 13: Race composition per university type (Source: SAllE member data)

Table 1: Race profile of first- and final-year students at IE departments at academic universities [18-20]

\begin{tabular}{|c|c|c|c|c|c|c|}
\hline Year & White & Black & Coloured & Indian & Total & $\% \mathrm{BCl}$ \\
\hline 1st \& 4th & 444 & 88 & 16 & 36 & 584 & $24 \%$ \\
\hline 1st year & 282 & 62 & 6 & 18 & 368 & $23 \%$ \\
\hline Final year & 162 & 26 & 10 & 18 & 216 & $25 \%$ \\
\hline
\end{tabular}

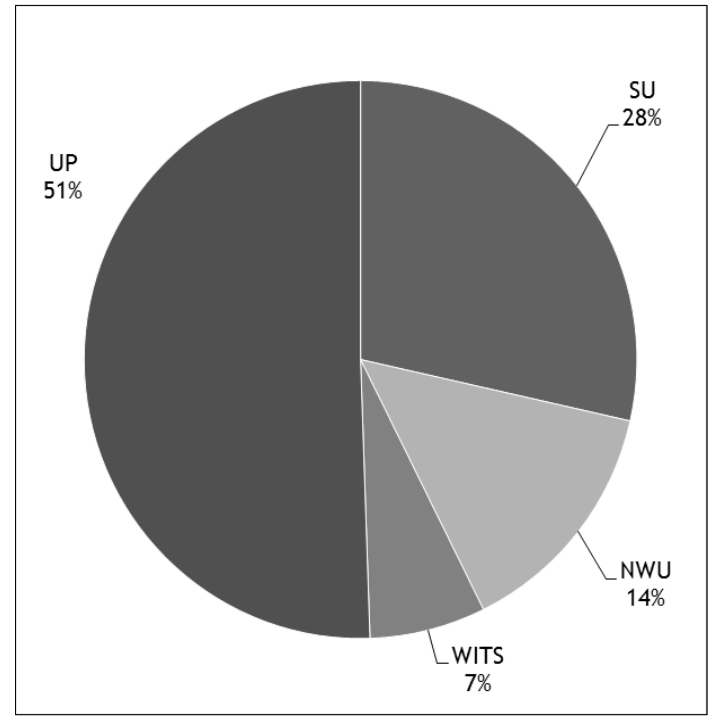

Figure 14: First-year student distribution in academic universities [18-20]

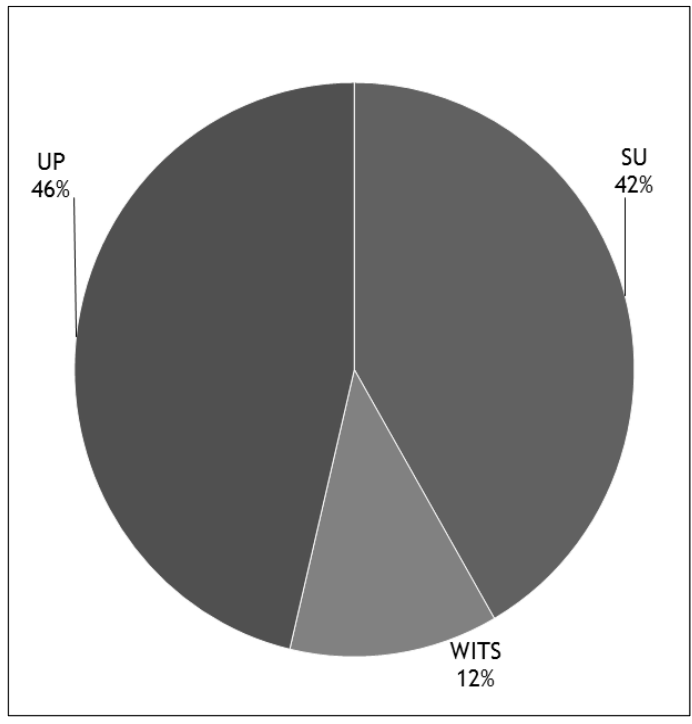

Figure 15: Final-year student distributions in academic universities [18-20]

Table 2 ranks the universities in terms of the percentage of $\mathrm{BCl}$ students from lowest to highest. Furthermore, the admission policy is summarised and additional clarifying notes are provided. Wits has the industrial engineering programme with the smallest enrolment, but its racial composition reflects South African demographics most closely. It is not clear whether the Wits admission policy makes it easier for students from previously disadvantaged groups to gain admission, given the fact that it does not have a sub-minimum requirement, unlike the other universities. All the other universities, and especially NWU and SU, have a long way to go before their student racial 
compositions are representative. Their position is probably exacerbated by their language policies, which do not guarantee English classes throughout their academic programmes and instead rely on translation services for specific modules. Both UP and SU have extended degree programmes, where students who are academically less-advanced may follow a programme containing additional courses to strengthen their academic foundations. Given that UP and SU currently have the largest IE student numbers and therefore the most capacity, the biggest impact on the racial composition, and therefore on transformation in terms of industrial engineering academic programmes, can be realised if more $\mathrm{BCl}$ students are encouraged to enrol in these programmes.

Table 2: Academic university industrial engineering department ranked on $\% \mathrm{BCl}$, with admission policies and explanatory notes

\begin{tabular}{|c|c|c|c|}
\hline $\begin{array}{l}\text { Academic } \\
\text { university }\end{array}$ & $\begin{array}{c}\% \\
\mathrm{BCI} \\
\text { rank }\end{array}$ & Admission policy & Additional notes \\
\hline $\begin{array}{l}\text { North-West } \\
\text { University (NWU) }\end{array}$ & 4 & $\begin{array}{l}\text { Mathematics level } 6(70-79 \%) \text { and } \\
\text { Physical Sciences level } 5(60-69 \%) \\
\text { Afrikaans or English level } 5(60-69 \%) \\
\text { [21]. }\end{array}$ & $\begin{array}{l}\text { New programme, only first-year } \\
\text { students' data available. }\end{array}$ \\
\hline $\begin{array}{l}\text { Stellenbosch } \\
\text { University (SU) }\end{array}$ & 3 & $\begin{array}{l}>60 \% \text { in Physics and }>70 \% \\
\text { Mathematics. } \\
\text { Admission score = Maths }+ \text { Physical } \\
\text { Science }+6 \times \text { avg. of matric excl. } \\
\text { Life Orientation. } \\
\text { Current target for } 2016 \text { is }>620 \text {, but } \\
>600 \text { is considered for } \mathrm{BCl} \text {. } \\
\text { Limited space per discipline [22]. }\end{array}$ & $\begin{array}{l}\text { The SU Engineering faculty has } \\
\text { followed a fully bilingual route over } \\
\text { the past two years, with parallel } \\
\text { tracks (Afrikaans and English) for } \\
\text { junior years and translation services } \\
\text { for senior years. An extended degree } \\
\text { programme is available for students } \\
\text { from previously disadvantaged } \\
\text { groups who do not meet the } \\
\text { minimum requirements. } \\
\text { Industrial engineering lags behind } \\
\text { other engineering disciplines at the } \\
\text { university with respect to \% } \mathrm{BCl} \text {. }\end{array}$ \\
\hline $\begin{array}{l}\text { University of } \\
\text { Pretoria (UP) }\end{array}$ & 2 & $\begin{array}{l}\text { Admission point system (APS). } \\
\text { Summary: If APS }>=36 \text {, and } \\
\text { Afrikaans or English }>60 \text {, Maths }>80 \\
\text { or }>70 \text { if Physical Science }>80 \text {, then } \\
\text { allowed into } 4 \text {-yr programme. } \\
\text { If APS } 30-36, \text { Maths }>70 \text { and Physical } \\
\text { Science }>60 \text {, then } 4 \text {-yr programme } \\
\text { possible with proficiency test, } \\
\text { otherwise extended programme } \\
\text { (Engage) } \\
\text { If APS } 25-30 \text {, Maths }>60 \text { and Physical } \\
\text { Science }>5 \text {, then Engage possible } \\
\text { after proficiency test [23]. }\end{array}$ & $\begin{array}{l}\text { The UP engineering programme has } \\
\text { been English-based for a number of } \\
\text { years, and this has had a positive } \\
\text { impact on making the programme } \\
\text { more accessible. }\end{array}$ \\
\hline $\begin{array}{l}\text { University of } \\
\text { Witwatersrand } \\
\text { (Wits) }\end{array}$ & 1 & $\begin{array}{l}\text { Admission point system (APS) where } \\
\text { English First Language and } \\
\text { Mathematics get a higher weight, } \\
\text { and Life Orientation a lower weight. } \\
\text { No minimum requirement in any } \\
\text { subject, but APS < } 36 \text { not likely to } \\
\text { be accepted [24]. }\end{array}$ & $\begin{array}{l}\% \mathrm{BCl} \text { is by far the highest, and the } \\
\mathrm{IE} \text { enrolment is representative of SA } \\
\text { demographics. Wits is a } \\
\text { predominantly English university, } \\
\text { and had a more liberal approach } \\
\text { during the apartheid years, which } \\
\text { resulted in greater accessibility for } \\
\text { other culture groups. }\end{array}$ \\
\hline
\end{tabular}

\subsection{Use and competence}

The survey collected data on the types of industrial engineering and engineering management activities in which respondents were involved in their current or previous employments, as well as their comfort in the area. The areas considered were:

- $\quad$ Project management;

- $\quad$ Productivity improvement;

- Work-study;

- $\quad$ Production engineering;

- $\quad$ Facility layout and material handling;

- Cost assessment and cost/benefit analysis; 
- Information system and systems design;

- Operations research and simulation;

- Logistics;

- Quality assurance;

- $\quad$ Automation and robotics;

- Technology or engineering management; and

- General management.

This was then used to calculate a utility complexity factor. This takes the complexity of an activity area and attributes a value, as perceived by the authors (e.g. the application of operations research was generally seen as more complex than work-study). This value then takes into account the experience/comfort factor, as selected by the professional, to calculate the score for each respondent. For example, if respondents reported that their responsibility included complex areas such as operations research, combined with feedback that they were comfortable in this area, the result would be a high score. Alternatively, if respondents had done work-study and were less comfortable, this would result in a much lower score. While the mechanics of the utility factor have not been discussed in detail here, it is nevertheless useful for comparison purposes in order to measure whether respondents have been exposed to and are suited for more complex tasks or simpler tasks. As a check to confirm the validity of the factor, there should be a correlation between earnings and the utility complexity factor, and Figure 16 indeed shows a strong correlation (owing to small sample sizes, the < ZAR 100,000 and > ZAR 2,000,000 categories were removed).

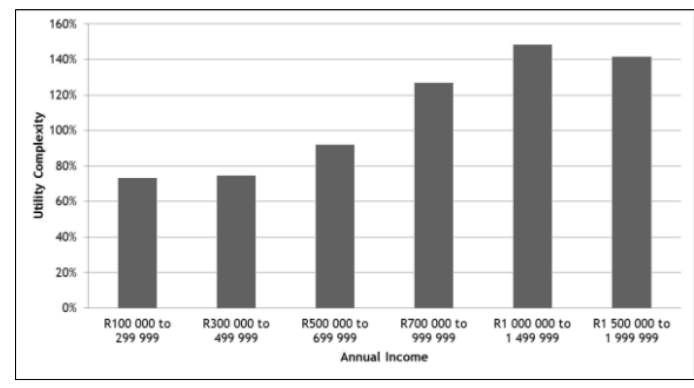

Figure 16: Utility complexity factor vs earnings (Source: IE Survey)

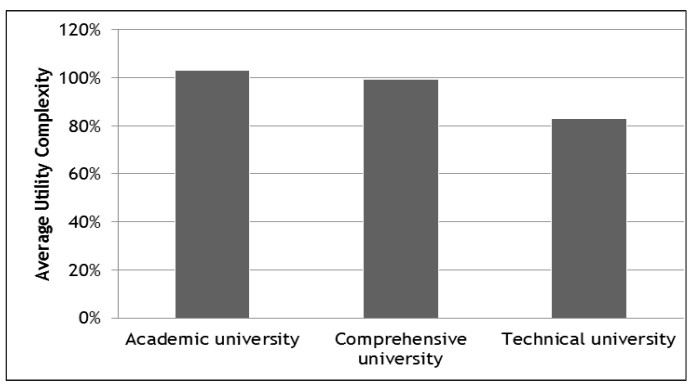

Figure 17: Average utility complexity factor vs university type (Source: IE Survey)

Figure 17 shows that IEs with a technical university background have a lower utility complexity factor than IEs with an academic university background. This is reflected and confirmed in the survey performed by LHA Management Consultants, which found that IEs with a BTech or NDip qualification had a more limited application in industry [16]:

- Figure 18 indicates that $50 \%$ of employers suggested that NDip skills were too low, and $33 \%$ suggested that BTech skills were too low.

- Figure 19 shows that the desire to appoint more graduates (that is, academic university graduates) far exceeds the desire to employ more NDip or BTech engineers.

This limited perceived utility of technically-qualified IEs not only divides the discipline, but also limits the transformation process within the industrial engineering discipline. From the figures above, it therefore seems that, while industrial engineering is recognised as a scarce skill in South Africa [13], the scarce skill requirement is mostly for IEs from academic universities. It seems therefore that the higher education process is not satisfying the demands of the country, in that the right mixture of IEs is not delivered to the market, or that the curriculum of technical universities falls short of that which could be more beneficial to employers. 


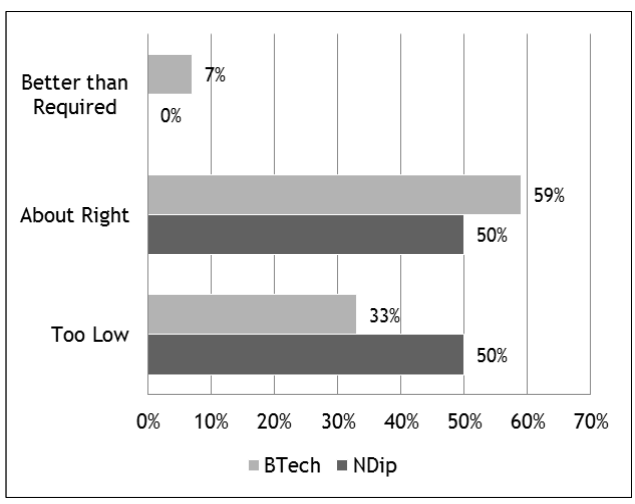

Figure 18: The level of competence and workplace-applicable skills of NDip/BTech graduates [16]

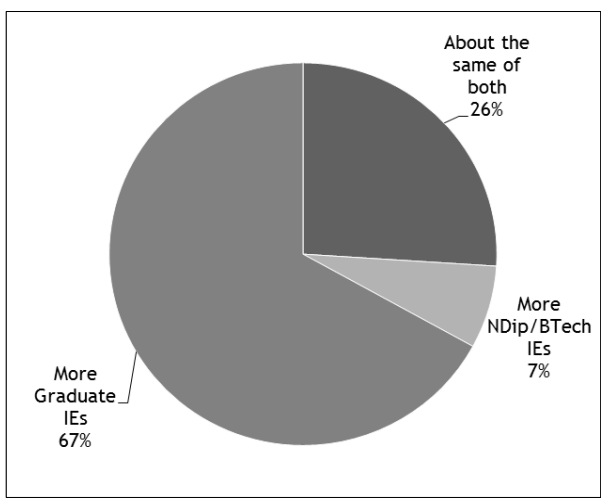

Figure 19: Employers' employment preference (NDip/BTech vs academic (graduate) engineers) [16]

\subsection{Income profiles}

The survey captured the gross income of all participants as shown Figure 20 (take note that the < ZAR 100,000 and > ZAR 2,000,000 participants were excluded due to the small sample size). As may be expected, Figure 21 illustrates that the number of years of experience has a strong correlation with income. It is interesting to note that there are a number of younger IEs with less than 15 years of experience who are top earners in this analysis.

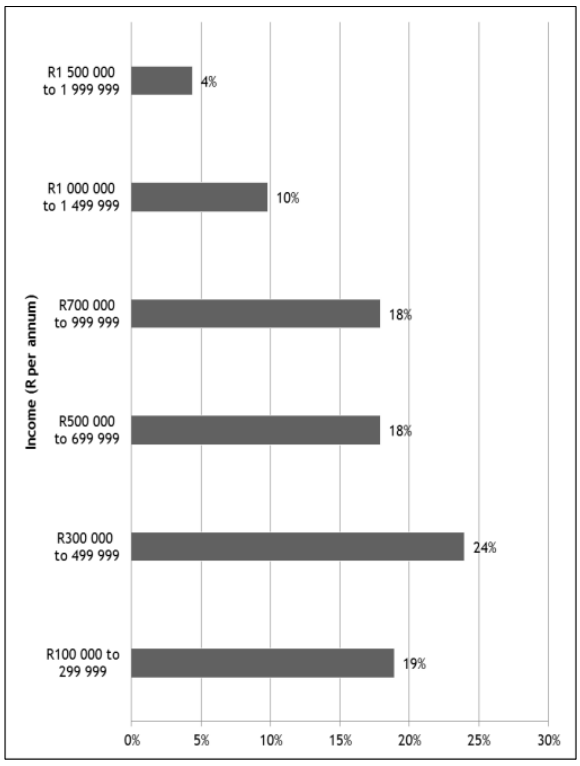

Figure 20: Gross income profile (Source: IE Survey)

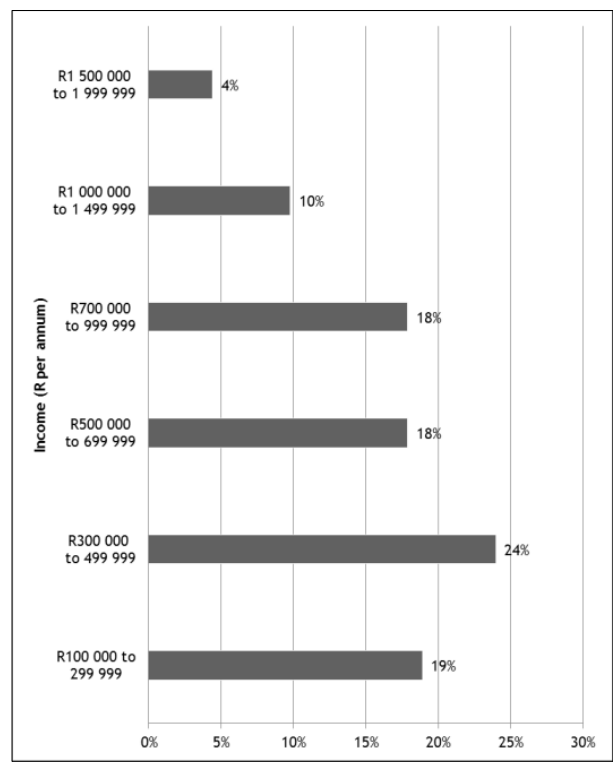

Figure 21: Gross income vs. experience (Source: IE Survey)

When income and gender are examined (Figure 22), it seems that female IEs have a similar income profile to their male counterparts, but that males become more dominant in the higher earning categories.

This can be further explored by analysing the disparity in terms of the experience of male and female IEs in each of these income categories. This is shown in Figure 23 and Figure 24. The number of years' experience seems to account partially for the under-representation of female IEs in the higher income categories; yet there are some male IEs with relatively little experience in the highest income category (predominantly found in the mining and finance industries). 


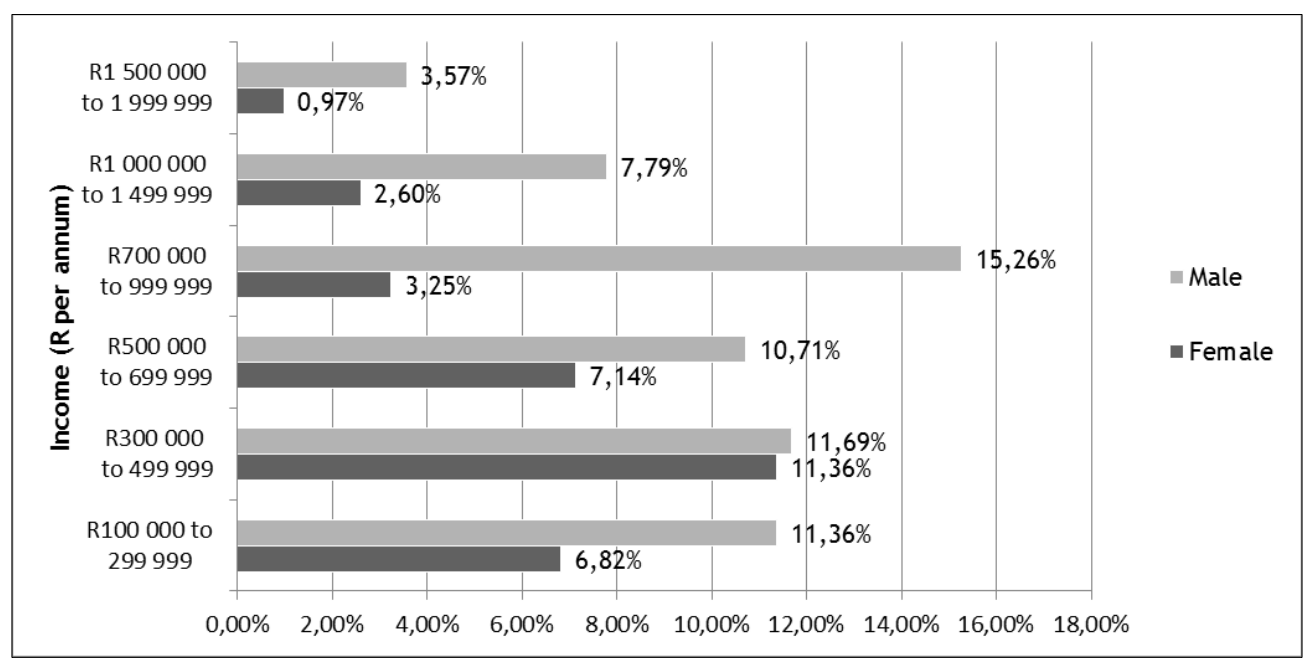

Figure 22: Gross income by gender (Source: IE Survey)

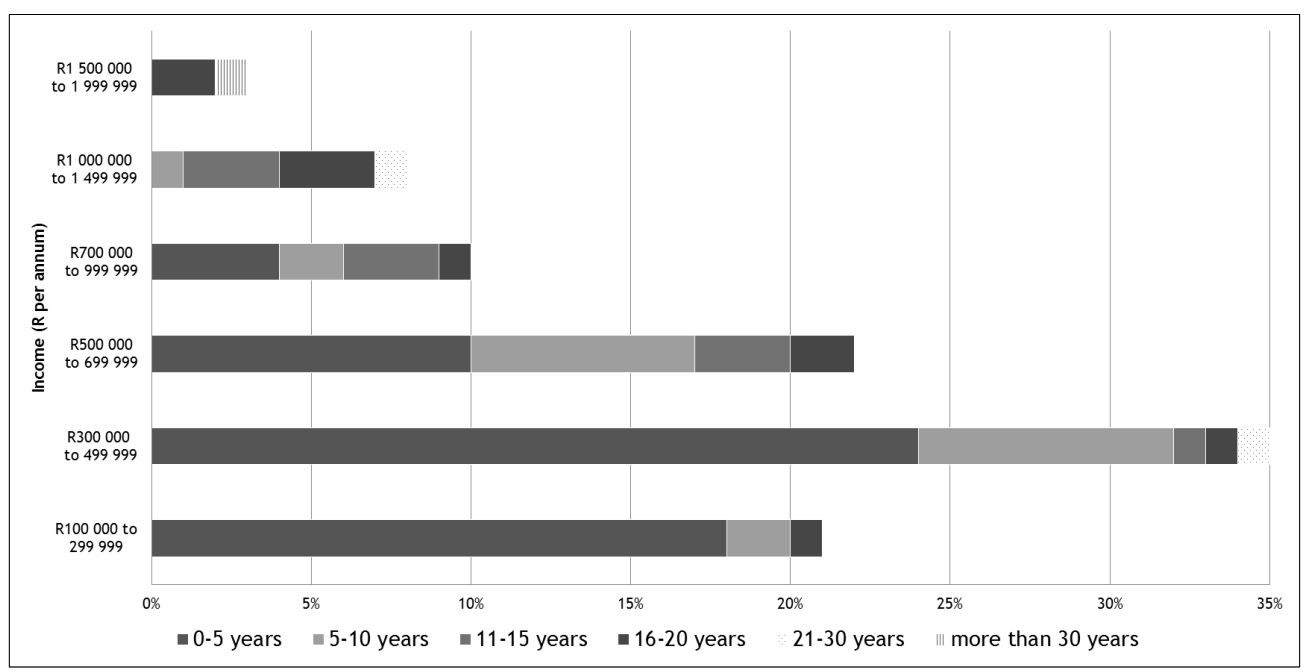

Figure 23: Number of years of experience of female IEs per income category (Source: IE Survey)

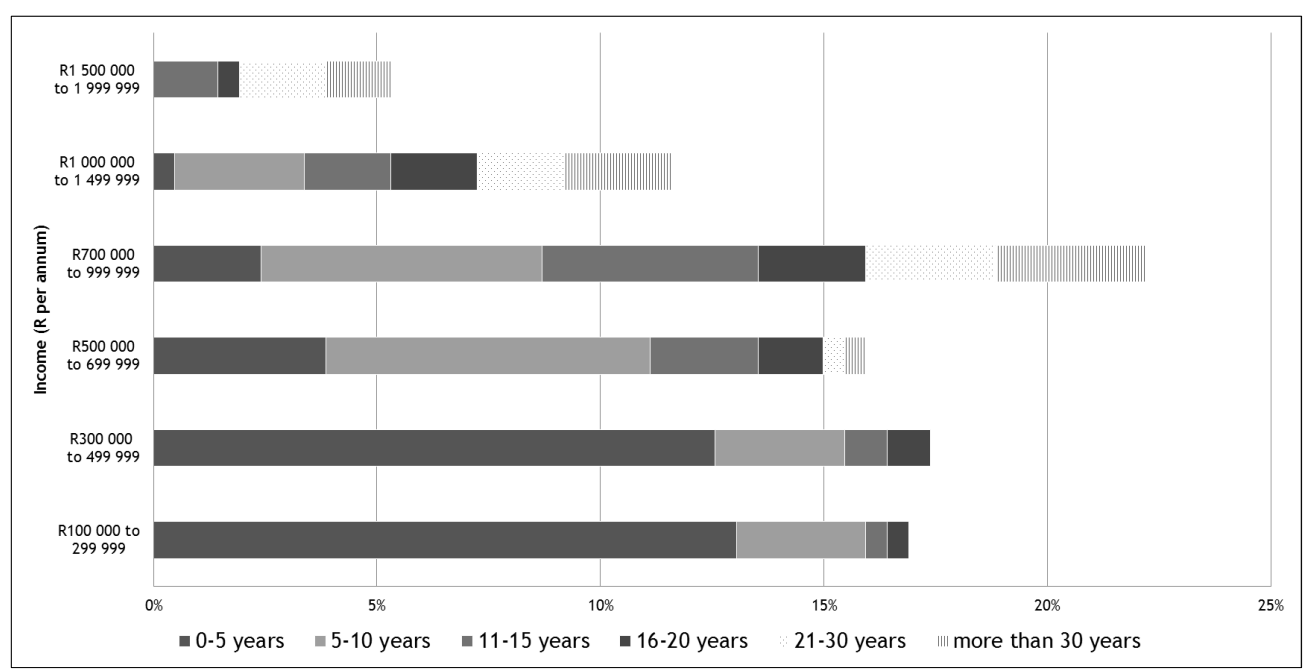

Figure 24: Number of years of experience of male IEs per income category (Source: IE Survey) 


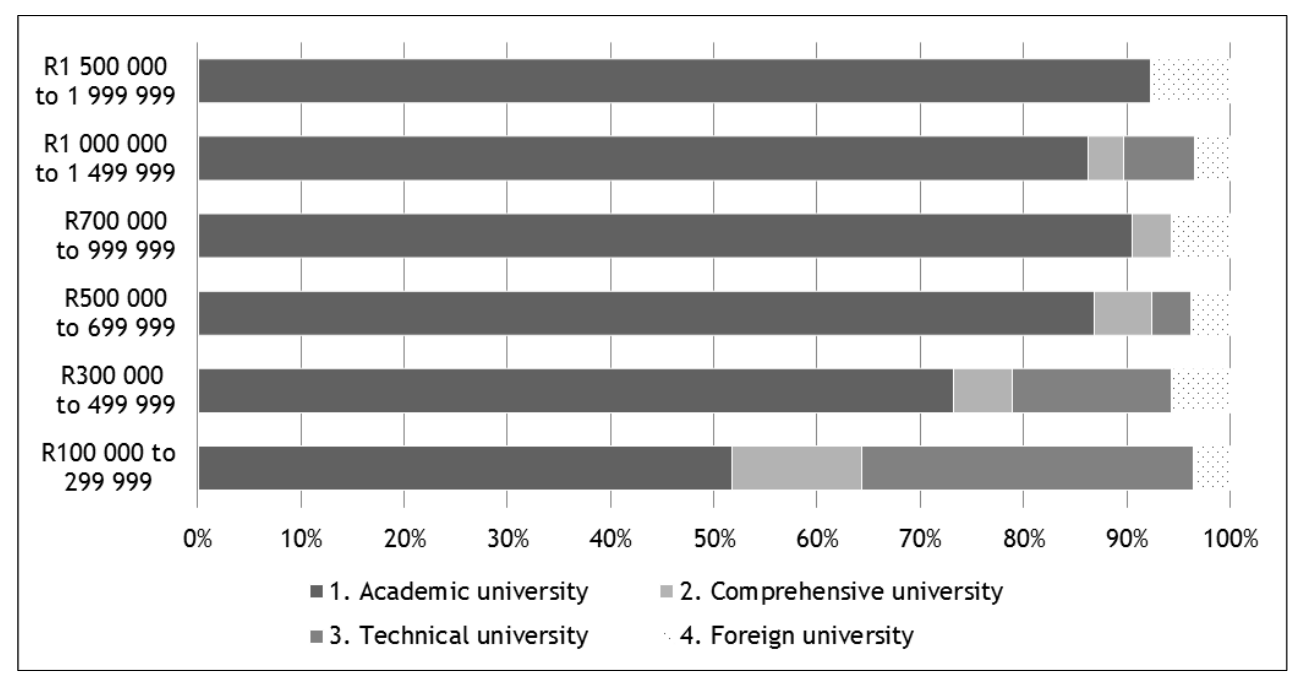

Figure 25: Gross income per university type (Source: IE Survey)

When income and university type are examined (Figure 25), the more limited career growth of the technical and comprehensive university graduate is very apparent. Academic university graduates seem to advance faster and earn significantly more in their careers.

\section{SUMMARY AND DISCUSSION}

This study has presented the history of industrial engineering in South Africa. This has highlighted the profession's roots in production engineering and its development in relation to the growth of the South African economy. Over the years, industrial engineering has become a strong and established discipline in South Africa, and is offered as an academic degree at four universities and as a technical qualification at nearly all the technical and comprehensive universities in South Africa.

In Section 3, the technology, economic, and educational drivers for industrial engineering in South Africa were presented. This highlighted that there seems to be a shortage of IEs in the country. This appears to be exacerbated by the constrained supply of maths and science matriculants. Furthermore, the shift in the economy from mining and manufacturing towards finance, real estate, and business services was identified. This appears to be mirrored in the technology and research trends that seem to indicate a shift from the traditional industrial engineering fields to technology and engineering management. Nonetheless, the traditional industrial engineering research categories generally seem to align with international technology trends, and the proportion of research fields of recent South African industrial engineering publication outputs seems to be comparable with international research trends.

Based on the identified need for more IEs, the study proceeded to investigate the supply of and demand for IEs in more detail. It was found that a relatively large proportion of IEs in South Africa (16\%) have obtained their IE qualifications abroad. Furthermore, just over $50 \%$ of IEs in South Africa hold academic degrees, while the rest hold qualifications from technical or comprehensive universities. Surprisingly, the manufacturing sector is still the largest employer of IEs. IEs are also poorly represented in government, which indicates a latent opportunity. It must be noted, however, that this sector is more sensitive about the racial composition of its workforce, which could explain the under-representation in this sector. This hypothesis is also echoed by the example of engineering capability degradation of local governments highlighted in Van Baalen et al. [25]. Another explanation may be that government prefers to subcontract activities requiring IE expertise when deemed necessary.

The study has also identified that IEs tend to be hired in small numbers, possibly making it difficult for young and inexperienced IEs to gain traction within their positions. The data also indicate that there are still more white IEs than black IEs, although the margin of this figure seems to be 
closing. Females IEs only account for around $20 \%$ to $25 \%$ of the number of their male counterparts within each racial group, but this ratio also appears to be increasing.

It appears that black IEs generally attain technical qualifications, while white IEs generally attain academic qualifications. This can be traced back to the major university IE programmes that are still largely training a majority of white students. This could be due to the specific enrolment requirements, stigma, or marketing of these programmes, and represents a major challenge for the future of industrial engineering in South Africa.

Furthermore, academic university IE graduates seem to have a better utility and application in industry and earn significantly more in their careers than graduates with technical university qualifications (BTech and NDip). Technical university graduates appear to have a more limited application in industry, which seeks more academic graduated IEs. One way to address this issue could lie in the enhancement of the curriculum of the technical universities so that they deliver more suitable technical IEs to industry.

As might be expected, the data indicate that IEs with more experience generally get paid more. Female IEs generally appear to have the same income distribution as their male counterparts; however, they are underrepresented in the higher income categories, which can partly be attributed to less experience.

\section{RECOMMENDATIONS}

This article is a first step in understanding the current disposition, opportunities, and challenges in the South African industrial engineering landscape. Future research is required to understand better the reasons for the issues raised and the most appropriate ways to address these issues.

One of the key findings from this research is that academic industrial engineering programmes do not deliver sufficient $\mathrm{BCI} I \mathrm{Es}$, and that most academic programmes do not meet transformation expectations. Black IEs are mostly educated in technical and comprehensive universities, while white IEs are predominantly from academic universities.

The result is that $\mathrm{BCI}$ IEs end up in positions where they are less influential and earn less, and are therefore not clear enablers of the drive to attract more young people from disadvantaged backgrounds to become IEs. This is likely hampering the growth of the discipline in significant industry sectors such as general government services, where the IE discipline needs to have more $\mathrm{BCl}$ IEs of the appropriate stature to grow in this sector.

It seems that opportunities to address this issue possibly lie with:

- Ensuring that more $\mathrm{BCl}$ industrial engineering students graduate from academic programmes, who could eventually be in a position to grow industrial engineering in the under-represented industry sectors. This represents an opportunity for academic programmes. Academic industrial engineering programmes need to understand why they fail to attract sufficient $\mathrm{BCl}$ students of the required standard, and need to find ways to encourage $\mathrm{BCl}$ students to enrol in academic universities.

- Developing and enhancing the curricula of the technical industrial engineering programmes to ensure the delivery of IEs to industry, addressing some of the shortcomings and lower utility and application that are currently experienced with these qualifications.

- $\quad$ Sensitising and encouraging employers in the under-represented industry sectors about the positive impact that IEs can have in their industries, and also equipping young IEs to suit these sectors better.

- Creating a working group within the industrial engineering community that consists of representatives from all the industrial engineering programmes, the largest employers, and SAlIE council representatives, to share data and find solutions to the representation challenge.

- Identifying successful $\mathrm{BCl}$ role models and using these role models to market industrial engineering in schools to attract stronger candidates from the $\mathrm{BCl}$ community. 
The research has attempted to make use of different data sources in order to investigate a variety of dimensions of IE in South Africa and to ensure a higher confidence in the research results. Nonetheless, certain limitations on the data should be appreciated when interpreting the results. The researchers were not able to establish with any degree of certainty what the total number of IEs working in South Africa is, and one of the limitations is knowing how representative the SAlIE membership data is of the industrial engineering population in South Africa. Furthermore, there might be a bias arising from which IEs took the time to respond to the survey and which IEs register as members with SAIIE. Nonetheless, due to the convergence of data from the different data sources, the authors deem the major conclusions from the research to be valid.

\section{REFERENCES}

[1] Salvendy, G. 2001. Handbook of industrial engineering: Technology and operations management. Wiley.

[2] SAllE definition of industrial engineering. Retrieved from http://www.saiie.co.za/. Accessed on 2 September 2015.

[3] IIE industrial engineering definition. Retrieved from https://www.iienet2.org/details.aspx?id=282. Accessed on 2 September 2015.

[4] Du Preez, N.D., Essmann, H.E., Louw, L., Schutte, C.S.L., Marais, S.J. \& Bam, W. 2015. Enterprise engineering textbook. $5^{\text {th }}$ edition, Stellenbosch University, Stellenbosch: Enterprise Engineering Group, Industrial Engineering.

[5] Du Preez, N.D. \& Pintelon, L. 1995. The industrial engineer: Caught between two revolutions? South African Journal of Industrial Engineering, 8(2).

[6] Sperotto, F. 2015. The development of the industrial engineering profession in South Africa, South African Journal of Industrial Engineering, 26(2), pp. 1-9.

[7] Dastkhan, H. \& Owlia, M.S. 2011. Study of trends and perspectives of industrial engineering research, South African Journal of Industrial Engineering, 20(1).

[8] Uys, J.W., Schutte, C.S. \& Esterhuizen, D. 2010. Trends in a South African industrial engineering journal: A textual information analysis perspective, South African Journal of Industrial Engineering, 21(1), pp. 1-16.

[9] Uys, J.W., Schutte, C.S. \& Van Zyl, W.D. 2011. Trends in an International industrial engineering research journal: A textual information analysis perspective. Presented at the Computers and Industrial Engineering 41, Los Angeles, pp. 884-893.

[10] Gross domestic product. Statistical Release P0441, August 2015.

[11] Van Hoogstraten, L. 2012. Results of the 2012 infrastructure sector research survey carried out by executive search firm Landelahni Business Leaders Amrop SA: Market contribution, Civil Engineering, 20(8), pp. 44-48.

[12] Botha, C., Petrarolo, D., Willemse, E., Cilliers, M., Seedat, M., Gunn, R. \& Rohrs, R. 2014. Meeting the demand for SIPs scarce skills: Industrial engineering. SAlIE.

[13] National Scarce Skills List: Top 100 Occupations in Demand. May 2014.

[14] SurveyMonkey. Retrieved from https: //www.surveymonkey.com/. Accessed on 20 August 2015.

[15] Schutte, C.S. 2011. SAlIE Presidential Address 2011. Presented at the SAIIE AGM, Johannesburg, pp. 123.

[16] LHA Management Consultants. 2015. Study of the work performance of NDip and BTech Industrial Engineers. SAIIE.

[17] Mid-year population estimates 2014. Statistical Release P0302, Jul. 2014.

[18] Yadavalli, S. 2015. Tuks IE Student Numbers. 07-Sep-2015.

[19] Hartmann, D. 2015. Wits IE Student Numbers. Johannesburg, 03-Sep-2015.

[20] Van Dyk, L. 2015. NWU IE Student Numbers. 01-Sep-2015.

[21] Minimum Admission requirements undergraduate studies Potchefstroom Campus 2016. 04-Dec-2014. Retrieved from http://www.nwu.ac.za/sites/www.nwu.ac.za/files/files/pc-potchefstroom-campus/ MinimumRequirementsToelatingsvereistes2016.pdf. Accessed on 7 September 2015.

[22] Universiteit Stellenbosch Fakulteits Ingenieurswese Toelatingsvereistes 2015. 07-Sep-2015. Retrieved from http://www0.sun.ac.za/programmes/assets/File/Ingenieurswese_Afr.docx. Accessed 2015-09-07

[23] University of Pretoria Engineering Yearbook 2015. 15-Dec-2014. Retrieved from http://www.up.ac.za/ media/shared/360/Year\%20Books\%202015/EBIT/ebit-part-1-engineering-2015.zp42447.pdf. Accessed on 7 September 2015.

[24] WITS School Mechanical, Industrial and Aeronautical Engineering Entry Requirements. Retrieved from http://www.wits.ac.za/academic/ebe/mecheng/undergraduate/22592/entry_requirements.html. Accessed on 7 September 2015.

[25] Van Baalen, S.M., Schutte, C.S. \& Von Leipzig, K. 2015. Capacity self-assessment as a catalyst for improved municipal service delivery, Journal of the South African Institution of Civil Engineering, 57(1) pp. 2-15. 